\title{
Risk Prediction of Early and Late Acquired Glomerular and Tubular Dysfunctions in Patients with Disorders of Carbohydrate Metabolism
}

\author{
Marina A. Ustinova ${ }^{1}$; Mikhail M. Batiushin, $\mathrm{PhD}, \mathrm{ScD}^{1}$; Sergey V. Vorobyev, $\mathrm{PhD}, \mathrm{ScD}^{1}$; \\ Natalia A. Kuzmenko, $\mathrm{PhD}^{1}$; Ekaterina Yu. Petrovskaya, $\mathrm{PhD}^{1}$; Vladimir A. Chistyakov, PhD, \\ $\mathrm{ScD}^{2}$; Vagif M. Ibragimov, $\mathrm{PhD}^{3}$; Irina V. Sarvilina, $\mathrm{PhD}, \mathrm{ScD}^{4^{*}}$ \\ ${ }^{1}$ Rostov-on-Don State Medical University, Rostov-on-Don, Russia \\ ${ }^{2}$ Laboratory of Experimental Mutagenesis, Academy of Biology and Biotechnology \\ of Rostov-on-Don State Federal University, Rostov-on-Don, Russia \\ ${ }^{3}$ Dagestan State Medical University, the Republic of Dagestan, Makhachkala, Russia \\ ${ }^{4}$ Medical Centre "Novomeditsina", Rostov-on-Don, Russia
}

\begin{abstract}
The purpose of this study was to create a new system for predicting the risk of glomerular and tubular dysfunctions (GTD) in patients with disorders of carbohydrate metabolism (DCM) based on standard parameters and new molecular markers for the development of kidney damage in patients with impaired glucose tolerance (IGT) and T2DM patients with diabetic nephropathy (DN).

Material and Methods: The study included 69 patients: 16 patients with IGT (Group 1), 28 T2DM patients with microalbuminuria (Group 2), and 25 T2DM patients with macroalbuminuria (Group 3), according to the inclusion/exclusion criteria in the research. All patients were stratified by the MDRD. The control group (Group 4) included 11 healthy individuals. The duration of DN was 10.5 years. At the stage of data collection and screening, the standard methods of identification of IGT, DM and DN were applied. Additional methods are included quantitative analysis of the level of $\alpha$-GST and $\pi$-GST, MMP-9 in urine by ELISA.

Result: Based on the data of standard methods of identification of early and late acquired GTD in patients with DCM and new methods for assessment of metabolic profile of urine, we propose new prognostic markers of renal glomerular and tubular lesions in patients with IGT and T2DM. (International Journal of Biomedicine. 2017;7(3):208-212.)
\end{abstract}

Key Words: diabetic nephropathy • glomerular dysfunctions • tubular dysfunctions • molecular markers • impaired glucose tolerance

\section{Abbreviations}

CKD, chronic kidney disease; DCM, disorders of carbohydrate metabolism; DN, diabetic nephropathy; eGFR, estimated glomerular filtration rate; FG, fasting glucose; GTD, glomerular and tubular dysfunctions; GST, glutathione S-transferase; IGT, impaired glucose tolerance; MAU, microalbuminuria; MacAU, macroalbuminuria; MMP-9, matrix metalloproteinase-9; OGTT, oral glucose tolerance test; T2DM, type 2 diabetes mellitus.

\section{Introduction}

About of $20 \%$ of middle-aged people and $35 \%$ of the population of older persons is characterized by varying degrees of IGT and symptoms of insulin resistance. ${ }^{(1)}$ In

*Corresponding author: Irina V. Sarvilina, PhD, ScD. General Director of Medical Centre "Novomeditsina», Rostov-onDon, Russian Federation.E-mail: isarvilina@mail.ru accordance with the current evaluation of the International Diabetes Federation, there will be 642 million patients with diabetes mellitus by $2040 .^{(2)}$

Epidemiological studies have considered MAU as risk factor for atherosclerosis, coronary artery disease, and other vascular disorders in patients with T2DM and IGT. ${ }^{(3-5)}$

In Russia, the prevalence of DN in T2DM is an average of $8 \%$; that is 5 times lower than world values. However, active screening of T2DM patients reveals that the true prevalence 
of DN exceeds registered cases in various regions of Russia by 2-8 times. ${ }^{(6)}$ The epidemiology of DN in T2DM has not been investigated sufficiently since it is extremely difficult to determine precisely the time when DN begins. The risk of MAU in prediabetic subjects is high, and probably prediabetic subjects are at higher risk of DN progression. ${ }^{(7)}$

Experimental and clinical trials performed between 1998 and 2014 showed that hyperglycemia, hyperlipidemia, a high level of creatinine in the blood, glomerular hyperfiltration, proteinuria, arterial hypertension, and anemia play an important role in the DN development in T2DM patients. ${ }^{(8-15)}$

The molecular pathogenesis of GTD in patients with DCM cannot be described only on the basis of standard clinical research methods. Modern methods and technologies of molecular analysis make it possible to discover new prognostic markers and to investigate pathways of formation of renal damage at various levels of functioning in patients with DCM.

The purpose of this study was to create a new system for predicting the risk of GTD in patients with DCM based on standard parameters and new molecular markers for the development of kidney damage in patients with IGT and T2DM patients with DN.

\section{Material and Methods}

The study protocol was reviewed and approved by the Ethics Committee of Rostov-on-Don State Medical University and Dagestan State Medical University. All participants provided the written informed consent. The study was prospective cohort comparative with parallel design and included 69 patients: 16 patients with IGT (Group 1), 28 T2DM patients with MAU (Group 2), and 25 T2DM patients with MacAU (Group 3), according to the inclusion/exclusion criteria in the research. All patients were stratified by the MDRD. The control group (Group 4) included 11 healthy individuals. Patients corresponded to the criteria for the classification of DN and CKD. ${ }^{(6,16,17)}$ The T2DM risks were evaluated with a special assessment designed by Tuomilehto (Finnish Type 2 Diabetes Risk Assessment Form). The duration of DN was 10.5 years. The duration of therapy (hypoglycemic drugs: glibenclamide, metformin, pioglitazone, insulin glargine; antihypertensive drugs: amlodipine, valsartan; hypolipidemic drug: fenofibrate; and antiplatelet drug: acetylsalicylic acid) was 9.2 years.

At the stage of data collection and screening, the standard methods of identification of IGT, DM and DN were applied: the assessment of medical history; physical examination; ambulatory blood pressure monitoring; ultrasonography of kidney (Doppler spectrum of the intrarenal arteries in conjunction with evaluation of the renal cortical echogenicity); complete blood count and urinalysis; blood glucose; OGTT; lipide profile; the serum levels of ALT, AST, pancreatic amylase, total bilirubin, creatinine, potassium, sodium, urea, and C-peptide; MAU and ketone bodies in urine; the estimation of T2DM compensation by $\mathrm{HbA} 1 \mathrm{c}$ levels; the assessment of kidney function by eGFR according to the CKD-EPI formula. ${ }^{(18)}$ Additional methods are included quantitative analysis of the level of $\alpha$-GST and $\pi$-GST, MMP9 in urine by ELISA. The following diagnostic medical equipment were used: SonoAce R3 (Samsung Medison, South Korea), Olympus AU640 (Olympus Corporation, Japan), Immulite 1000 Immunoassay System (Siemens, USA) "Unimed" (Russia), Randox Laboratories Ltd. (UK), Luminex MAGPIX (USA), standard reagent kits ALPCO Alpha GST ELISA (UK), Biotrak Cell Proliferation ELISA System (UK).

Statistical analysis was performed using Statsoft Statistica V 12.0 Baseline characteristics were summarized as frequencies and percentages for categorical variables and as mean \pm SEM for continuous variables. Comparisons between four groups were performed with the one-way ANOVA with Tukey's post-hoc test. Group comparisons with respect to categorical variables are performed using chi-square tests with Yates correction or, alternatively, Fisher's exact test when expected cell counts were less than 5. A probability value of $P<0.05$ was considered statistically significant.

\section{Results}

We have verified the next groups of patients with IGT and T2DM: a group of patients with Stage 1 of DN (prenephropathy stage with normoalbuminuria, $n=16$ ) and a group of patients with Stages 2 and 3 of DN (MAU and MacAU, n=53). Clinical and anamnestic characteristics of patients and healthy individuals are presented in Table 1.

Parameters of complete blood count and urinalysis were in the range of reference values in patients with IGT. Ultrasonographic signs of DN were detected in all patients with T2DM and DN (high resistive indices were obtained in the region of the arcuate or the interlobar arteries in patients with elevated serum creatinine levels).

There were unidirectional dynamics of mean values of parameters of blood metabolic profile in all groups of patients compared to the control group: FG (Group 1: 6.17 \pm 0.1 $\mathrm{mmol} / \mathrm{l}$; Group 2: $8.1 \pm 0.4 \mathrm{mmol} / \mathrm{l}$; Group 3: $8.69 \pm 0.4 \mathrm{mmol} / \mathrm{l}$; and Group 4: $5.26 \pm 0.2 \mathrm{mmol} / \mathrm{l} ; F=14.6019, P=0.0000 ; P_{2}$ $=0.0001, P_{3-4}=0.0000$ ), OGTT (Group 1: $6.9 \pm 0.2 \mathrm{mmol} / \mathrm{l}$; Group 2: $8.3 \pm 0.3 \mathrm{mmol} / \mathrm{l}$; Group 3: $10.0 \pm 0.7 \mathrm{mmol} / \mathrm{l}$; and Group 4: $5.8 \pm 0.2 \mathrm{mmol} / 1 ; F=11.5656, P=0.0000 ; P_{2-4}=0.0120$, $P_{3-4}=0.0000$ ), and HbA1c (Group 1: $6.91 \pm 0.2 \%$; Group 2: 6.97 $\pm 0.3 \%$; Group 3: $7.68 \pm 0.3 \%$; and Group 4: $5.29 \pm 0.1 \%$; $F=8.3345, P=0.0001 ; P_{1-4}=0.0130, P_{2-4}=0.0034, P_{3-4}=0.0000$ ).

Asignificant increase in the average values of the $C$-peptide level in the blood was recorded in patients with IGT compared with values of this parameter in healthy individuals (Group 1: 926 $\pm 47.8 \mathrm{pmol} / \mathrm{l}$; Group 4: 743.4 $\pm 45.4 \mathrm{pmol} / \mathrm{l} ; P_{1-4}=0.0138$ ). Significantly increased blood levels of total cholesterol (Group 1: $6.4 \pm 0.3 \mathrm{mmol} / \mathrm{l}$; Group 2: $5.9 \pm 0.2 \mathrm{mmol} / \mathrm{l}$; Group 3: $5.9 \pm 0.2$ $\mathrm{mmol} / \mathrm{l}$; and Group 4: $5.2 \pm 0.2 \mathrm{mmol} / \mathrm{l} ; F=2.9643, P=0.0373$; $P_{1-4}=0.0197$ ) and LDL-C (Group 1: $3.45 \pm 0.1 \mathrm{mmol} / 1$; Group 4: $2.76 \pm 0.1 \mathrm{mmol} / 1 ; P_{1-4}=0.0000$,) were found in the group of patients with IGT compared to the control group. A statistically significant increased atherogenicity index was identified in groups of patients with IGT and T2DM+MacAU compared to the control group (Group 1: $4.4 \pm 0.1$; Group 3: $4.1 \pm 0.1$; Group 4: $\left.3.67 \pm 0.2 ; P_{1-4}=0.0015, P_{3-4}=0.0389\right)$. 
Table 1.

Clinical and anamnestic characteristics of patients with DCM and healthy individuals

\begin{tabular}{|c|c|c|c|c|c|}
\hline Parameter & $\begin{array}{c}\text { Group } 1 \\
(n=16)\end{array}$ & $\begin{array}{c}\text { Group } 2 \\
(\mathrm{n}=28)\end{array}$ & $\begin{array}{c}\text { Group } 3 \\
(\mathrm{n}=25)\end{array}$ & $\begin{array}{c}\text { Group } 4 \\
(n=11)\end{array}$ & Statistics \\
\hline Sex (male/female) & $5 / 11$ & $3 / 25$ & $9 / 16$ & $3 / 8$ & \\
\hline Age, years & $51.1 \pm 1.9$ & $54.0 \pm 1.9$ & $55.8 \pm 2.0$ & $46.2 \pm 2.8$ & $\begin{array}{l}F=2.9173, P=0.0395 ; P_{1-2}=0.7645, P_{1-3}=0.4159, \\
P_{1-4}=0.5551, P_{2-3}=0.9011^{1}, P_{2-4}=0.1053, P_{3-4}=0.0327\end{array}$ \\
\hline BMI, $\mathrm{kg} / \mathrm{m}^{2}$ & $30.6 \pm 0.8$ & $33.4 \pm 1.1$ & $31.7 \pm 1.4$ & $26.6 \pm 1.3$ & $\begin{array}{l}F=3.9390, P=0.0114 ; P_{1-2}=0.3961, P_{1-3}=0.9294, \\
P_{1-4}=0.2785, P_{2-3}=0.6951, P_{2-4}=0.0062, P_{3-4}=0.0691\end{array}$ \\
\hline $\begin{array}{l}\text { The degree of obesity } \\
\text { Underweight } \\
\left(25.0-29.9 \mathrm{~kg} / \mathrm{m}^{2}\right) \\
\text { Grade } 1 \\
\left(30.0-34.9 \mathrm{~kg} / \mathrm{m}^{2}\right) \\
\text { Grade } 2 \\
\left(35.0-39.9 \mathrm{~kg} / \mathrm{m}^{2}\right) \\
\text { Grade } 3\left(>40.0 \mathrm{~kg} / \mathrm{m}^{2}\right)\end{array}$ & $\begin{array}{l}5 \\
8 \\
3 \\
-\end{array}$ & $\begin{array}{l}5 \\
13 \\
7 \\
3\end{array}$ & $\begin{array}{l}8 \\
10 \\
5 \\
2\end{array}$ & $\begin{array}{l}9 \\
2 \\
- \\
-\end{array}$ & $\begin{array}{c}\chi^{2}=14.609, P=0.00218 \\
\chi^{2}=3.247, P=0.35508 \\
\text { Yates' } \chi^{2}=1.935, P=0.58600 \\
\text { Yates' } \chi^{2}=0.667, P=0.88094\end{array}$ \\
\hline $\begin{array}{l}\text { Duration of IGT, } \\
\text { months }\end{array}$ & $5.3 \pm 1.3$ & - & - & - & \\
\hline $\begin{array}{l}\text { Duration of T2DM, } \\
\text { months }\end{array}$ & - & - & $20.2 \pm 3.8$ & - & \\
\hline $\begin{array}{l}\text { Duration of arterial } \\
\text { hypertension, months }\end{array}$ & $9.6 \pm 0.8$ & $17.3 \pm 3.0$ & $25.3 \pm 4.7$ & - & $\begin{array}{l}F=4.0217, P=0.0225 ; P_{1-2}=0.3447, P_{1-3}=0.0180, \\
P_{2-3}=0.2277\end{array}$ \\
\hline
\end{tabular}

Table 2.

Parameters of renal function in patients with DCM and healthy individuals

\begin{tabular}{|c|c|c|c|c|c|}
\hline Parameter & $\begin{array}{l}\text { Group } 1 \\
(\mathrm{n}=16)\end{array}$ & $\begin{array}{c}\text { Group } 2 \\
(\mathrm{n}=28)\end{array}$ & $\begin{array}{c}\text { Group } 3 \\
(\mathrm{n}=25)\end{array}$ & $\begin{array}{c}\text { Group } 4 \\
(\mathrm{n}=11)\end{array}$ & Statistics \\
\hline \multicolumn{6}{|c|}{ Blood laboratory tests } \\
\hline $\begin{array}{l}\text { Urea, } \\
\mathrm{mmol} / \mathrm{l}\end{array}$ & $5.0 \pm 0.3$ & $5.7 \pm 0.2$ & $5.4 \pm 0.3$ & $4.3 \pm 0.4$ & $\begin{array}{l}F=3.5125, P=0.0192 ; P_{1-2}=0.3042, P_{1-3}=0.7610, \\
P_{1-4}=0.5018, P_{2-3}=0.8276, P_{2-4}=0.0147^{2}, P_{3-4}=0.0885\end{array}$ \\
\hline $\begin{array}{l}\text { Creatinine, } \\
\mu \mathrm{mol} / 1\end{array}$ & $73.7 \pm 3.6$ & $76.0 \pm 2.5$ & $80.1 \pm 3.1$ & $70 \pm 1.8$ & $\begin{array}{l}F=1.6351, P=0.1883 ; P_{1-2}=0.9485, P_{1-3}=0.4575, \\
P_{1-4}=0.8979, P_{2-3}=0.6909, P_{2-4}=0.6009, P_{3-4}=0.1757\end{array}$ \\
\hline $\begin{array}{l}\text { Potassium, } \\
\mathrm{mmol} / \mathrm{l}\end{array}$ & $4.5 \pm 0.03$ & $4.2 \pm 0.03$ & $4.5 \pm 0.06$ & $4.1 \pm 0.03$ & $\begin{array}{l}F=17.9198, P=0.0000 ; P_{1-2}=0.0001, P_{1-3}=\mathrm{NaN}, \\
P_{1-4}=0.0000, P_{2-3}=0.0000, P_{2-4}=0.5162, P_{3-4}=0.0000\end{array}$ \\
\hline $\begin{array}{l}\text { Sodium, } \\
\mathrm{mmol} / 1\end{array}$ & $147.5 \pm 0.8$ & $150.1 \pm 0.9$ & $139.4 \pm 0.6$ & $147.1 \pm 0.3$ & $\begin{array}{l}F=41.0321, P=0.0000 ; P_{1-2}=0.1079, P_{1-3}=0.0000, \\
P_{1-4}=0.9921, P_{2-3}=0.0000, P_{2-4}=0.0994, P_{3-4}=0.0000\end{array}$ \\
\hline $\begin{array}{l}\text { eGFR, } \\
\mathrm{ml} / \mathrm{min} / 1.73 \mathrm{~m}^{2}\end{array}$ & $81.7 \pm 3.5$ & $79.3 \pm 2.4$ & $81.3 \pm 3.1$ & $90.2 \pm 3.2$ & $\begin{array}{l}F=1.7084, P=0.1724 ; P_{1-2}=0.9434, P_{1-3}=0.9998, \\
P_{1-4}=0.3913, P_{2-3}=0.9510, P_{2-4}=0.1213, P_{3-4}=0.2812\end{array}$ \\
\hline \multicolumn{6}{|c|}{ Urine laboratory tests } \\
\hline $\begin{array}{l}\text { Urine specific } \\
\text { gravity, g/1 }\end{array}$ & $1018.8 \pm 1.7$ & $1021 . \pm 1.2$ & $1022.9 \pm 1.3$ & $1017.8 \pm 1.9$ & $\begin{array}{l}F=2.1719, P=0.0982 ; P_{1-2}=0.7009, P_{1-3}=0.2063, \\
P_{1-4}=0.9791, P_{2-3}=0.7116, P_{2-4}=0.5111, P_{3-4}=0.1397\end{array}$ \\
\hline $\begin{array}{l}\text { Albumin } \\
\mathrm{mg} / 24 \mathrm{~h}\end{array}$ & - & $7.1 \pm 1.5$ & $155.9 \pm 24.6$ & - & $P=0.0000$ \\
\hline $\begin{array}{l}\alpha-\mathrm{GST} \\
\mathrm{ng} / \mathrm{ml}\end{array}$ & $56.1 \pm 2.1$ & $79.8 \pm 1.3$ & $85.5 \pm 1.5$ & $34.5 \pm 1.4$ & $\begin{array}{l}F=166.3471, P=0.0000 ; P_{1-2}=0.0000, P_{1-3}=0.0000 \\
P_{1-4}=0.0000, P_{2-3}=0.0252, P_{2-4}=0.0000, P_{3-4}=0.0000\end{array}$ \\
\hline $\begin{array}{l}\pi \text {-GST, } \\
\mathrm{ng} / \mathrm{ml}\end{array}$ & $2.0 \pm 0.03$ & $1.4 \pm 0.03$ & $1.4 \pm 0.04$ & $2.4 \pm 0.1$ & $\begin{array}{l}F=98.1620, P=0.0000 ; P_{1-2}=0.0000, P_{1-3}=0.0000 \\
P_{1-4}=0.0000, P_{2-3}=\mathrm{NaN}, P_{2-4}=0.0000, P_{3-4}=0.0000\end{array}$ \\
\hline $\begin{array}{l}\text { MMP-9, } \\
\mathrm{ng} / \mathrm{ml}\end{array}$ & $317.8 \pm 16.5$ & $663.0 \pm 10.5$ & $679.6 \pm 13.6$ & $154.4 \pm 6.4$ & $\begin{array}{l}F=319.0550, P=0.0000 ; P_{1-2}=0.0000, P_{1-3}=0.0000, \\
P_{1-4}=0.0000, P_{2-3}=0.7364, P_{2-4}=0.0322, P_{3-4}=0.0446\end{array}$ \\
\hline
\end{tabular}


In patients with $\mathrm{T} 2 \mathrm{DM}+\mathrm{MAU}$, we found a significantly increased blood level of ALT (Group 2: 27.6 $1.8 \mathrm{U} / 1$; Group 4: $\left.21.13 \pm 1.9 \mathrm{U} / 1 ; P_{2-4}=0.0000\right)$. The blood level of pancreatic amylase (Group 3: 72.9 $2.3 \mathrm{U} / 1$; Group 4: $39.3 \pm 1.8 \mathrm{U} / 1 ; P_{3-4}=0.0000$ ) was significantly increased in patients with $\mathrm{T} 2 \mathrm{DM}+\mathrm{MacAU}$ compared to the healthy individuals. The parameters of renal function in patients with DCM are presented in Table 2.

Regression analysis demonstrated the lack of influence of clinical and demographic predictors on the actual number of outcomes with the appearance of GTD determined by the combination of new molecular diagnostic parameters of urine. Therefore, the risk of GTD in patients with DCM can be assessed using new diagnostic markers, which is demonstrated by correlation analysis between interrelated metabolic parameters of blood and urine. In patients with DCM and healthy controls, correlation analysis between the level of eGFR, $\alpha$-GST, $\pi$-GST and MMP-9 in urine, on the one hand, and blood metabolic profile, parameters of kidney function, on the other hand, has revealed key laboratory tests of blood and urine predicting the occurrence and progression of GTD in IGT and T2DM with MAU and MacAU. The following correlations were found: eGFR with urea concentration in blood (Group 3: $r=-0.59$, $P<0.001$ ), blood creatinine (Group 1: $r=-0.93, P<0.001$, Group 2: $r=-0.68, P<0.001$ ) and albuminuria (Group 3: $r=0.48, P<0.05$ ); a concentration of $\alpha$-GST in urine with blood level of total cholesterol (Group 2: $r=-0.39 ; P<0.01$ ), blood sodium (Group 3: $r=-0.54 ; P<0.001$ ), blood urea (Group 2: $r=0.44, P<0.01$ ) and MMP-9 in urine (Group 2: $r=0.54, P<0.001$ ); a concentration of $\pi$-GST in urine with urea and creatinine in the blood (Group 3: $r=0.39, P<0.05$ and $r=0.42, P<0.05$, respectively).

\section{Discussion}

Determining the level of albumin in urine in patients with DCM is proven and necessary for early detection and evaluation of the progression of $\mathrm{DN} .{ }^{(19)}$ However, the detection of early changes in glomerular and tubular kidney functions in DCM patients requires the identification and introduction of new specific and sensitive diagnostic markers to the clinical practice. All these changes correlate with high expression of urine proteins, reflecting the progression of epithelial-mesenchymal transition (EMT) and changes in the extracellular matrix (ECM) of the kidneys in DCM patients.

A large number of typical morphological changes is the result of EMT: thickening of basal membranes and the glomerular mesangial matrix, and the expansion of tubulointerstitial space due to an increase in ECM. All EMT events are regulated by a variety of intracellular pathways.

The regularities of conjugate dynamics of hormonal and metabolic profiles of blood and urine have demonstrated changes in the functioning of the hepatorenal axis in patients with DCM.

Based on obtained data about the increase of the blood C-peptide level, it is necessary to note its probable protective effect in the course of development of functional and structural disorders in the renal tissue in DCM. The combined decrease in glomerular hyperfiltration and albuminuria in patients with IGT requires further studies, and additional data are required on the modulating effects of the different ranges of C-peptide concentrations for the formation of early and late GTD in patients with DCM. ${ }^{(20)}$

The revealed dyslipidemia in patients with IGT and T2DM with the presence of signs of GTD indicated their great prognostic value in combination with other indicators of kidney function. Dyslipidemia can lead to a decrease in the release of NO synthase via the phosphatidylinositol-3-kinase pathway in the endothelium of glomerular vessels, which contributes to the impairment of the filtration function of kidneys and a reduction in eGFR. (21) $^{2}$

We found an increase in the concentration of MMP9 in the urine in DCM patients, the most pronounced with T2DM and MAU/MacUA. An increase in the concentration of urine MMP9 in patients with IGT, even in the absence of MAU, indicates an excessive accumulation of it in ECM, which subsequently leads to the development of DN. MMP9 is a participant in the process of remodeling in the ECM in DN.

With a greater degree of probability, the concentration of GSTs in urine may be an early predictor of acquired tubular dysfunctions in patients with DCM. GSTs are primarily the cytosolic enzymes, which are detected in high concentrations in renal tubules. $\alpha$-GST is primarily expressed in proximal tubules, whereas $\pi$-GST is expressed in the distal tubules and collecting tubules. ${ }^{(22)}$ Due to the damage to tubules, the concentration of GSTs increases in urine, which has been demonstrated in our study. ${ }^{(23)}$ The increase in the level of GSTs in the urine indicates the functioning of a compensatory mechanism in the response to pronounced oxidative stress in the lesion of renal tissue in DCM. ${ }^{(24)}$

Based on the data of standard methods of identification of early and late acquired GTD in patients with DCM and new methods for assessment of metabolic profile of urine, we propose new prognostic markers of renal glomerular and tubular lesions in patients with IGT and T2DM. The diagnostic markers of acquired GTD in patients with DCM interact with each other and with other molecules participating in universal pathways, which are the main causes for EMT formation and changes in ECM: Smad, p38 MAPK, TLRs, Wnt, mTOR, Notch, small GTPase and Hedgehog, and PI3K/ AKT signaling pathways.

\section{Conclusion}

We identified potential new biomarkers allowing us to predict the risk of acquired GTD in patients with DCM (IGT, T2DM). The results of the study are essential for practical implementation of non-invasive diagnostic tests for early detection of nephropathy in DCM. The study made it possible to clarify the molecular mechanisms in the development of acquired GTD in patients with IGT and T2DM. The study of signaling pathways and molecules expressing, secreting and forming ECM may be a basis for the prophylaxis of acquired GTD in patients with DCM.

\section{Competing interests}

The authors declare that they have no competing interests. 


\section{References}

1. Morley JE. Diabetes and aging: epidemiologic overview. Clin Geriatr Med. 2008;24(3):395-405. doi: 10.1016/j. cger.2008.03.005.

2. International Diabetes Federation. IDF Diabetes Atlas7th Edition. Available from: http://www.diabetesatlas.org/.

3. Dell'Omo G, Penno G, Giorgi D, Di Bello V, Mariani M, Pedrinelli R. Association between high-normal albuminuria and risk factors for cardiovascular and renal disease in essential hypertensive men. Am J Kidney Dis. 2002; 40(1):1-8.

4. Garg J, Bakris G. Microalbuminuria: marker of vascular dysfunction, risk factor for cardiovascular disease. Vasc Med. 2002;7(1):35-43.

5. Wang XL, Lu JM, Pan CY, Tian H, Li CL. A comparison of urinary albumin excretion rate and microalbuminuria in various glucose tolerance subjects. Diabet Med. 2005;22(3):332-5.

6. Dedov I, Shestakova M, Mayorov A. Standards of specialized diabetes care. Edited by 8th Edition. Diabetes Mellitus 2017;20(1S):1-112. doi: 10.14341/DM20171S8. [in Russian].

7. Bahar A, Makhlough A, Yousefi A, Kashi Z, Abediankenari S. Correlation between prediabetes conditions and microalbuminuria. Nephrourol Mon. 2013 Spring; 5(2):741-4. doi:10.5812/numonthly.7646.

8. King P, Peacock I, Donnelly R. The UK Prospective Diabetes Study (UKPDS): clinical and therapeutic implications for type 2 diabetes. Br J Clin Pharmacol. 1999;48(5):643-8.

9. ADVANCE Collaborative Group, Patel A, MacMahon S, Chalmers J, Neal B, Billot L, Woodward M, et al. Intensive blood glucose control and vascular outcomes in patients with type 2 diabetes. N Engl J. Med. 2008;358(24):2560-72. doi: 10.1056/NEJMoa0802987.

10. Wood AJ, Churilov L, Perera N, Thomas D, Poon A, MacIsaac RJ, et al. Estimating glomerular filtration rate: Performance of the CKD-EPI equation over time in patients with type 2 diabetes. J Diabetes Complications. 2016;30(1):4954. doi: 10.1016/j.jdiacomp.2015.08.025.

11. Hall JE, Brands MW, Dixon WN, Smith MJ Jr. Obesity-induced hypertension. Renal function and systemic hemodynamics. Hypertension.1993;22(3):292-9.

12. Rask-Madsen C, King G. Vascular complications of diabetes: mechanisms of injury and protective factors. Cell
Metab. 2013;8(17):20-33. doi: 10.1016/j.cmet.2012.11.012. 13. Brenner BM, Cooper ME, de Zeeuw D, Keane WF, Mitch WE, Parving HH, et al.; RENAAL Study Investigators. Effects of losartan on renal and cardiovascular outcomes in patients with type 2 diabetes and nephropathy. N Engl J Med. 2001;345(12):861-9.

14. Kostadaras A. Risk Factors for Diabetic Nephropathy. Available from: http://www.kidneydoctor.com/dm.htm.

15. Stauffer ME, Fan T. Prevalence of anemia in chronic kidney disease in the United States. PLoS One. 2014;9(1):e84943 doi: 10.1371/journal.pone.0084943.

16. American Diabetes Association. 15. Diabetes advocacy. Diabetes Care. 2017;40(Suppl 1):S128-S129.

17. Haneda M, Utsunomiya K, Koya D, Babazono T, Moriya T, Makino H, et al.; Joint Committee on Diabetic Nephropathy. A new Classification of Diabetic Nephropathy 2014: a report from Joint Committee on Diabetic Nephropathy. J Diabetes Investig. 2015; 6(2):242-6. doi: 10.1111/jdi.12319.

18. Ketteler M, Block GA, Evenepoel P, Fukagawa M, Herzog CA, McCann L, et al.Executive summary of the 2017 KDIGO Chronic Kidney Disease-Mineral and Bone Disorder (CKD-MBD) Guideline Update: what's changed and why it matters. Kidney Int. 2017; 92(1):26-36. doi: 10.1016/j. kint.2017.04.006.

19. Roshan B, Stanton RC. A story of microalbuminuria and diabetic nephropathy. J Nephropathology. 2013;2(4):234-40. doi:10.12860/JNP.2013.37.

20. Nordquist L, Wahren J. C-Peptide: the missing link in diabetic nephropathy? Rev Diabet Stud. 2009;6(3):203-10. doi 10.1900/RDS.2009.6.203

21. Dabla PK. Renal function in diabetic nephropathy. World J Diabetes. 2010; 1(2):48-56. doi:10.4239/wjd.v1.i2.48.

22. Sundberg AG, Appelkvist EL, Backman L, Dallner G. Urinary pi-class glutathione transferase as an indicator of tubular damage in the human kidney. Nephron.1994;67(3):308-16.

23. Vaidya VS, Ferguson MA, Bonventre JV. Biomarkers of acute kidney injury. Annu Rev Pharmacol Toxicol. 2008;48:463-93.

24. Sharma M, Gupta S, Singh K, Mehndiratta M, Gautam A, Kalra O, et al. Association of glutathione-S-transferase with patients of type 2 diabetes mellitus with and without nephropathy. Diabetes Metab Syndr. 2016;10(4):194-197. doi: 10.1016/j.dsx.2016.06.006. 